\title{
PENGARUH DEBT TO EQUITY RATIO, PROFITABILITY DAN FIRM SIZE TERHADAP EFFETIVE TAX RATE SERTA DAMPAKNYA TERHADAP DIVIDEND PAYOUT RATIO
}

\author{
Toni Gunawan ${ }^{1)}$ : Endang Rusdianti ${ }^{2)}$ \\ toni gunawano8@yahoo.co.id ${ }^{1}$; Endang_rusdianti@usm.ac.id ${ }^{2)}$
}

Magister Manajemen, Universitas Semarang, Semarang, Indonesia

\section{Info Artikel}

Sejarah Artikel:

Diterima :03-11-2018

Disetujui ;21-11-2018

Dipublikasikan ;07-042018

Keywords:

Debt to Equity Ratio, Profitability (ROA), Firm Size, Efective Tax Rate, dan Dividend Payout Ratio

\begin{abstract}
Abstrak
Penelitian ini dilakukan untuk menguji pengaruh Debt to Equity Ratio, Profitability dan Firm Size terhadap Efective Tax Rate serta dampaknya terhadap Dividend Payout Ratio. Tujuan dari penelitian ini adalah untuk mengukur dan menganalisis pengaruh Efective Tax Rate dan rasio-rasio keuangan perusahaan (Debt to Equity Ratio, Profitability dan Firm Size) terhadap Dividend Payout Ratio pada perusahaan-perusahaan yang terdaftar di Bursa Efek Indonesia pada periode 2012 - 2016. Dan diperoleh sampel sebanyak 16 perusahaan. Teknik analisis yang digunakan menggunakan Structural Equation Modeling (SEM).

Hasil penelitian menunjukkan hubungan signifikan antara variabel profitabilitas, Profitability dan Firm Size dengan Efective Tax Rate dan Profitability dan Firm Size dengan Dividend Payout Ratio . Penelitian ini juga menunjukkan hubungan tidak signifikan antara Debt to Equity Ratio dengan Efective Tax Rate dan variabel Debt to Equity Ratio dan Efective Tax Rate dengan Dividend Payout Ratio. Pada penelitian ini menunjukkan bahwa Efective Tax Rate tidak terbukti memediasi hubungan antara Debt to Equity Ratio, Profitability dan Firm Size terhadap Dividend Payout Ratio.
\end{abstract}

\section{THE EFFECT OF DEBT TO EQUITY RATIO, PROFITABILITY AND FIRM SIZE ON EFFETIVE TAX RATE AND ITS IMPACT ON DIVIDEND PAYOUT RATIO}

\section{Abstract}

This research was conducted to examine the effect of Debt to Equity Ratio, Profitability and Firm Size on Effective Tax Rate and its impact on the Dividend Payout Ratio. The purpose of this study was to measure and analyze the effect of Effective Tax Rate and company financial ratios (Debt to Equity Ratio, Profitability and Firm Size) on the Dividend Payout Ratio of companies listed on the Indonesia Stock Exchange in the period 2012-2016. And obtained a sample of 16 companies. The analysis technique used is using Structural Equation Modeling (SEM).

The results showed a significant relationship between the variables of profitability, Profitability and Firm Size with Effective Tax Rate and Profitability and Firm Size with Dividend Payout Ratio. This study also shows an insignificant relationship between Debt to Equity Ratio with Effective Tax Rate and Debt to Equity Ratio and Effective Tax Rate with Dividend Payout Ratio. In this study shows that Effective Tax Rate is not proven to mediate the relationship between Debt to Equity Ratio, Profitability and Firm Size to the Dividend Payout Ratio

\footnotetext{
Alamat korespondensi :

Magister Manajemen, Universitas Semarang, j1 Soekarno-Hatta Semarang, Indonesia

E-mail: toni_gunawano8@yahoo.co.id
} 


\section{PENDAHULUAN}

Kebijakan dividen merupakan bagian yang tidak terpisahkan dari keputusan perusahaan. Ketika perusahaan memperoleh laba maka akan membuat suatu keputusan pengalokasian dari laba tersebut. Apakah laba yang diperoleh perusahaan dibagikan kepada pemegang saham dalam bentuk dividen atau akan ditahan untuk keperluan reinvestment yang dapat digunakan untuk mendanai kegiatan operasionalnya. Apabila perusahaan memutuskan untuk membagikan dividen maka jumlah laba ditahan berkurang, sehingga sumber pendanaan internal juga berkurang. Sebaliknya, jika perusahaan memutuskan untuk tidak membagikan dividen maka jumlah laba ditahan bertambah, sumber pendanaan internal juga bertambah. Di sini peran manajemen perusahaan di tuntut untuk mengambil keputusan yang tepat dalam kebijakan dividen, hal ini terkait dengan hal-hal yang terkait dengan kebijakan dividen itu sendiri antara lain kepuasan investor atas investasi yang di tanamkan di perusahaan tersebut, pajak serta investasi dari perusahaan itu sendiri di masa yang akan datang. Maka dari itu, kebijakan dividen mempunyai dampak yang sangat penting bagi perusahaan maupun investor yang menanamkan modalnya pada perusahaan tersebut (Perpatih, 2016).

Faktor yang diiduga mempengaruhi kebijakan dividen adalah pajak Salah satu upaya perencanaan pajak (tax planning) adalah dengan melakukan kebijakan dividen yaitu menunda untuk melakukan pembagian dividen dengan menentukan porsi laba di tahan yang lebih besar atau menahan seluruh laba yang di peroleh perusahaan, sehingga pajak atas dividen juga ditunda pembayarannya. Yang kedua yaitu DER menggambarkan kemampuan perusahaan dalam mengakses pasar modal yang digambarkan dengan kemampuan berhutang (Janifairus dkk, 2013). Sehingga semaking tinggi rasio hutang akan berpengaruh terhadap kebijakan pembagian dividen. Ketiga Profitability diduga mempengaruhi kebijakan dividen, seringkali dalam pengamatan yang dilakukan investor menunjukan bahwa sebuah perusahaan dengan tingkat pengembalian (profit) yang tinggi atas investasi biasanya tidak banyak menggunakan pendanaan dengan utang, dengan demikian maka perusahaan dapat membiayai sebagian besar kebutuhan pendanaan mereka dengan dana yang dihasilkan secara internal atau dengan keuntungan yang dihasilkan sendiri (Bansaleg, dkk., 2014). Faktor lain yang diduga mempengaruhi kebijakan dividen yaitu Firm Size. Perusahaan yang memiliki aset besar atau yang sudah mapan cenderung lebih mempunyai akses yang lebih mudah dan lebih luas dalam pasar modal dibandingkan dengan perusahaan yang mempunyai size kecil, Dengan demikian semakin besar ukuran perusahaan semakin besar pula dividen yang dibagikan kepada para investor.

Di dalam tax preference theory menyatakan bahwa karena adanya pajak terhadap keuntungan dividen dan capital gains maka para investor lebih menyukai capital gains karena dapat menunda pembayaran pajak. Jika capital gain dikenakan pajak dengan tarif lebih rendah dari pada pajakatas dividen, maka saham yang memiliki pertumbuhan tinggi menjadi lebih menarik. Tetapi sebaliknya jika capital gain dikenai pajak yang samadengan pendapatan atas dividen, maka keuntungan capital gain menjadiberkurang. Namun demikian pajak atas dividen karena pajak atas capital gain baru dibayar setelah saham dijual, sementara pajak atas dividen harus dibayar setiap tahun setelah pembayaran dividen. Maka jika manajemen cenderung mempercayai tax preference theory maka perusahaan harus menahan seluruh keuntungan yang diperolehnya. Atas hal itulah maka variabel effective tax rate dapat ditempatkan sebagai 
variable intervening karena menurut teori tersebut pajak akan mempengaruhi kebijakan dividen.

\section{TELAAH PUSTAKA}

Menurut Brigham\& Houston (2004) menyebutkan ada tiga teori dari preferensi investor yaitu:

1. Dividend irrelevance theory adalah suatu teori yang menyatakan bahwa kebijakan dividen tidak mempunyai pengaruh, baik terhadap nilai perusahaan maupun biaya modalnya.Dengan demikian kebijakan dividen sebenarnya tidak relevan untuk dipersoalkan.

2. Bird in the hand Theory. Menurut Gordon dan Litner, tingkat keuntungan yang disyaratkan akan naik apabila pembagian dividen dikurangi karena investor lebih yakin terhadap penerimaan dividen daripada kenaikan nilai modal (capital gain) yang akan dihasilkan dari laba ditahan. Pendapat Gordon dan Litner oleh MM diberi nama bird in the hand fallacy. Gordon dan Litner beranggapan investor memandang bahwa satu burung di tangan lebih berharga daripada seribu burung di udara.

3. Tax preference theory adalah suatu teori yang menyatakan bahwa karena adanya pajak terhadap keuntungan dividen dan capital gains maka para investor lebih menyukai capital gains karena dapat menunda pembayaran pajak. Jika capital gain dikenakan pajak dengan tarif lebih rendah dari pada pajakatas dividen, maka saham yang memiliki pertumbuhan tinggi menjadi lebih menarik. Tetapi sebaliknya jika capital gain dikenai pajak yang sama dengan pendapatan atas dividen, maka keuntungan capital gain menjadi berkurang.

Berdasarkan ketiga konsep teori tersebut, perusahaan dapat melakukan hal-hal sebagai berikut :

1. Jika manajemen percaya bahwa dividend irrelevance theory dari Modigliani dan Miller itu benar maka perusahaan tidak perlu memperhatikan besarnya dividen yang harus dibagikan.

2. Jika perusahaan perusahaan menganut bird in thand theory maka perusahaan harus membagi seluruh EAT (Earning After Tax) dalam bentuk dividen.

3. Jika manajemen cenderung mempercayai tax preference theory maka perusahaan harus menahan seluruh keuntungan.

\section{- Pengaruh DER terhadap Effective tax rate}

Semakin besar hutang maka semakin kecil tax rate dan sebaliknya semakin kecil hutang, tax rate akan semakin besar. Penelitian yang dilakukan Hanum dan Zulaikha(2013) menyatakan adanya hubungan yang antara effective tax rate dengan debt to equity ratio (leverage). Sejalan dengan Hanum dan Zulaikha (2013), Alfandia (2017) mengungkapkan pula bahwa perusahaan lebih memilih memperbesar hutang daripada modal sendiri karena ada keuntungan penghematan biaya pajak sementara jika menggunakan modal sendiri, biaya hutang akan lebih kecil dan berdampak pada laba yang meningkat sebagai dasar perhitungan pajak. Dari pernyataan di atas maka dapat disusun hipotesis penelitian sebagai berikut:

H1: DER berpengaruh terhadap Effective tax rate

\section{- Pengaruh Profitability terhadap Effective tax rate}

Alfandia (2017) mengungkapkan bahwa apapun kebijakan pendanaan yang digunakan, pajak menjadi pertimbangan yang paling penting. Sebuah perusahaan akan berusaha untuk membayar hutang pajak yang lebih rendah. Faktor pajak 
sendiri diproksikan ke dalam laba setelah pajak (Earnings After Tax - EAT).Hal ini terlihat jelas bahwa berapapun laba yang dihasilkan pasti akan mempengaruhi nilai pajak yang dibayarkan. Semakin tinggi laba perusahaan maka semakin tinggi pula pajak yang dibayarkan dan sebaliknya. Darmawan dan Sukarta (2014) memberikan bukti bahwa ROA (Return on Asset) yang merupakan proksi dari profitabilitas perusahaan dapat mempengaruhi perusahaan dalam melakukan tinggi rendahnya laba yang dibayarkan. Dari pernyataan di atas maka dapat disusun hipotesis penelitian sebagai berikut:

H2: Profitability berpengaruh terhadap Effective tax rate.

\section{- Pengaruh Firm Size terhadap Effective tax rate}

Semakin besar ukuran perusahaan, maka perusahaan akan lebih mempertimbangkan risiko dalam hal mengelola beban pajaknya. Perusahaan yang termasuk dalam perusahaan besar cenderung memiliki sumber daya yang lebih besar dibandingkan perusahaan yang memiliki skala lebih kecil untuk melakukan pengelolaan pajak. Sumber daya manusia yang ahli dalam perpajakan diperlukan agar dalam pengelolaan pajak yang dilakukan oleh perusahaan dapat maksimal untuk menekan beban pajak perusahaan (Darmawan dan Sukarta, 2014). Penelitian yang dilakukan oleh Dewinta dan Setiawan(2016) menyatakan bahwa menyatakan bahwa firm size berpengaruh positif dan signifikan terhadap tax. Dari pernyataan di atas maka dapat disusun hipotesis penelitian sebagai berikut:

H3:firm size berpengaruh terhadap Effective tax rate

\section{- Pengaruh DER terhadap DPR}

Debt to equity ratio mencerminkan kemampuan perusahaan dalam memenuhi seluruh kewajibannya, yang ditunjukkan oleh berapa bagian modal sendiri yang digunakan untuk membayar hutang. Oleh karena itu, semakin rendah DER akan semakin tinggi kemampuan perusahaan untuk membayar semua kewajibannya. Jika beban hutang tinggi, maka kemampuan perusahaan untuk membagi dividen akan semakin rendah. Penelitian ini dibuktikan pula oleh Perpatih (2016) yang menunjukkan hasil yang signifikan antara hubungan DER dengan DPR. Dari pernyataan di atas maka dapat disusun hipotesis penelitian sebagai berikut:

H4: DER berpengaruh terhadap DPR

\section{- Pengaruh Profitability terhadap DPR}

Dari hasil penelitian yang dilakukan menunjukkan bahwa kebijakan jumlah pembagian dividen perusahaan dipengaruhi oleh Profitability. Selain itu penelitian Janifairus (2013) konsisten dengan penelitian Perpatih (2016), Nufiati (2015) dan Utami dan Robin (2015).Dari pernyataan di atas maka dapat disusun hipotesis penelitian sebagai berikut:

H5: Profitability berpengaruh terhadap DPR.

\section{- Pengaruh Firm Size terhadap DPR}

Penelitian yang dilakukan olehMarietta dan Sampurno (2013) menyatakan bahwa menyatakan bahwa firm size berpengaruh positif dan signifikan terhadap dividend payout ratio. Penelitian tersebut konsisten dengan penelitian Utami dan Robin (2015)yang membuktikan bahwa ukuran perusahaan dapat mempengaruhi DPR.Dari pernyataan di atas maka dapat disusun hipotesis penelitian sebagai berikut:

H6:Firm Size berpengaruh terhadap DPR

- Pengaruh Effective tax rate terhadap DPR 
Penelitian yang dilakukan oleh Gill, et al (2010) menunjukan bahwa pajak memeiliki hubungan positif dengan dividen. Mereka menyimpulkan bahwa sebagaimana kewajiban pajak mengalami kenaikan atau penurunan, maka preferensi untuk pembayaran pajak juga mengalami kenaikan atau penurunan. Hal ini menunjukan hubungan yang positif antara pajak dan pembayaran dividen.Dari pernyataan di atas maka dapat disusun hipotesis penelitian sebagai berikut: H7: Effective tax rate berpengaruh terhadap DPR

\section{Kerangka Pemikiran Teoritis}

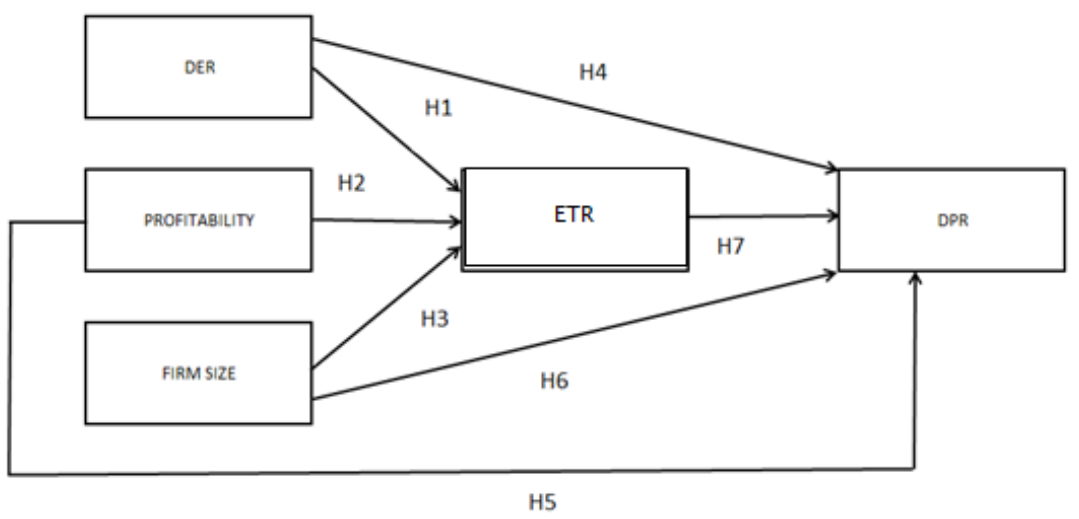

\section{METODE PENELITIAN}

\section{Populasi dan Teknik Pengambilan Sampel}

Populasi dalam penelitian ini adalah perusahaan-perusahaan yang terdaftar di Bursa Efek Indonesi (BEI) periode 2012 sampai dengan 2016 sejumlah 567. Teknik pengambilan sampel penelitian menggunakan metode purposive sampling dengan kriteria sebagai berikut:

a. Perusahaan yang terdaftar di Bursa Efek Indonesia periode 2012-2016.

b. Perusahaan tersebut selalu menyajikan laporan keuangan setiap periode pengamatan.

c. Perusahaan mengalami keuntungan (profit) periode pengamatan.

d. Perusahaan tersebut membagikan dividen setiap periode pengamatan yaitu periode 2012-2016.

Jumlah sampel yang memenuhi kriteria dalam penelitian ini adalah sejumlah 16 perusahaan.

\section{Jenis dan Sumber Data}

Penelitian ini menggunakan data sekunder berupa laporan keuangan dari perusahaan-perusahaan BEI yang membagikan dividen selama 5 tahun untuk periode tahun buku 2012 sampai dengan 2016. Data diambil dari web site BEI yaitu http//:www.idx.co.id dengan mengambil laporan yang telah di publikasikan oleh BEI.

\section{Definisi Operasional Variabel}


Berdasarkan telaah pustaka dan kerangka pemikiran teoritis serta hipotesis yang diajukan, maka definisi operasional variabel penelitian dapat diidentifikasi seperti yang ditunjukkan dalam tabel sebagai berikut:

Tabel Definisi Operasional Variabel

\begin{tabular}{|c|c|c|c|c|}
\hline $\begin{array}{l}\mathrm{N} \\
\mathrm{O}\end{array}$ & Variabel & Definisi Operasional & $\begin{array}{l}\text { Skala } \\
\text { Pengukur }\end{array}$ & n Pengukura \\
\hline 1. & $\begin{array}{l}\text { Debt to } \\
\text { Equity } \\
\text { Ratio(DER) }\end{array}$ & $\begin{array}{l}\text { Debt to Equity Ratio adalah } \\
\text { perbandingan antara total hutang } \\
\text { usahadengan modal yang } \\
\text { dimiliki }\end{array}$ & Rasio & $\begin{array}{l}\text { Total Debt } \\
\text { Shareholder } \\
\text { Equity }\end{array}$ \\
\hline 2 & $\begin{array}{l}\text { Profitability } \\
\text { (ROA) }\end{array}$ & $\begin{array}{l}\text { Profitability adalah kemampuan } \\
\text { perusahaan dalam menghasilkan } \\
\text { laba dari keseluruhan aset yang } \\
\text { dimiliki }\end{array}$ & Rasio & $\frac{\text { EAT }}{\text { Total Asset }}$ \\
\hline 3. & Firm SIze & $\begin{array}{l}\text { Firm Size adalah ukuran } \\
\text { perusahaan yang diukur dari } \\
\text { total aset yang dimiliki. }\end{array}$ & Rasio & LnTotalAsset \\
\hline 4. & $\begin{array}{l}\text { Tarif Pajak } \\
\text { (ETR) }\end{array}$ & $\begin{array}{l}\text { Tarif Pajak adalah perbandingan } \\
\text { antara biaya pajak tahun berjalan } \\
\text { terhadap pretax income }\end{array}$ & Rasio & $\frac{\text { Biaya Pajak }}{\text { PreTax Income }}$ \\
\hline 5 . & $\begin{array}{l}\text { Dividen } \\
\text { Payout Ratio }\end{array}$ & $\begin{array}{l}\text { Dividen Payout Ratio adalah } \\
\text { perbandingan antara dividen per } \\
\text { share (DPS) terhadap earning } \\
\text { per share (EPS) }\end{array}$ & Rasio & $\frac{\text { DPS }}{E P S}$ \\
\hline
\end{tabular}

Sumber : dikembangkan untuk penelitian ini, 2018

\section{Teknik dan Analisis}

\section{Analisis Analisis Statistik Deskriptif}

Analisis statistik deskriptif digunakan dalam penelitian ini untuk memberikan gambaran atau deskripsi mengenai variabel-variabel penelitian. Penelitian ini menggunakan tabel distribusi frekuensi yang menunjukkan kisaran teoritis, kisaran aktual, nilai rata-rata (mean) dan standar deviasi (Ghozali, 2014).

\section{Analisis Data}

Dengan berdasarkan model penelitian yang diformulasikan diatas, teknik yang tepat untuk digunakan dalam menganalisis adalah Menurut Hair et al (2006). Model dengan aras jamak bisa dianalisis dengan menggunakan SEM (Stuctural Equation Modelling). Model persamaan strukturan ini adalah penerapan beberapa model secara kompak yakni; model analisis faktor, model analisis jalur dan model analisis regresi (Ghozali, 2014).

Pertimbangan dalam menggunakan metode Partial Least Square (PLS) adalah. Konsekuensi proses iterasi berbasis varian adalah adanya pengabaian efek multikolinearitas antar indikator dan variabel laten. Keunggulan metode ini adalah (Abdilah, 2015,):

a. Metode ini tepat digunakan untuk model prediksi yang bertujuan memprediksi hubungan efek kausalitas pada jenjang variabel laten.

b. Mampu memodelkan banyak variabel dependen dan variabel independen (model kompleks).

c. Mampu mengelola masalah multikolinearitas antar variabel independen. 
d. Hasil tetap kokoh maupun (robust) walaupun terdapat data yang tidak normal dan hilang (missing value).

e. Lebih kuat secara praktis karena alebih efisien dalam proses eksekusi.

f. Dapat mengolah data sample kecil, kokoh terhadap deviasi asumsi normalitas, mengukur indikator-indikator reflektif dan formatif, dan mengukur model rekursif.

g. Tidak mensyaratkan data berdistribusi normal.

h. Dapat digunakan pada data dengan tipe skala berbeda yaitu nominal, ordinal dan kontinus.

\section{Uji Kualitas Data}

\section{Model Struktural atau Inner Model (Uji Hipotesis)}

Model struktural atau uji hipotesis dievaluasi dengan melihat nilai koefisien parameter dan nilai $\mathrm{t}$ statistik serta signifikansi koefisien parameter tersebut. Nilai $\mathrm{t}$ statistik diperoleh dari hasil bootstraping dengan membagi nilai koefisien parameter dengan nilai standar errornya.

Model evaluasi PLS berdasarkan pada pengukuran prediksi yang mempunyai sifat non parametrik. Seperti yang telah dijelaskan sebelumnya, model struktural atau uji hipotesis dievaluasi dengan melihat nilai koefisien parameter dan nilai t statistik serta signifikansi koefisien parameter tersebut. Nilai koefisien parameter yang dilambangkan dengan "b" diketahui dari kolom Original Sample Estimate Nilai t statistik diperoleh dari hasil bootstraping dengan membagi nilai koefisien parameter dengan nilai standar errornya.

Dalam menilai model PLS dengan melihat R-Square untuk setiap variabel laten dependen. Perubahan nilai R-Square dapat digunakan untuk menilai pengaruh variabel laten independen tertentu terhadap variabel laten dependen apakah mempunyai pengaruh substantive.

Inner Weights bertujuan untuk mengetahui hubungan antar variabel penelitian dengan model bootstrap didapatkan t-statistik untuk mengukur apakah hipotesis tersebut diterima atau ditolak. Menurut Hartono dalam Jogiyanto dan Abdillah (2009) adapun kaidah penolakan dan penerimaan hipotesis sebagai berikut:

1. Ho diterima dan Ha ditolak jika $t$ hitung $<\mathrm{t}$ tabel $( \pm 1,96)$

2. Ho ditolak dan Ha diterima jika $t$ hitung $>\mathrm{t}$ tabel $( \pm 1,96)$

Analisis jalur (Path Analysis) melihat pengaruh langsung (direct effect) dan tidak langsung (indirect effect) dapat diketahui dengan cara mengalikan koefisien standardized (tanpa konstanta) yang dihasilkan dari analisis Results for inner weights. Koefisien pengaruh langsung dibandingkan dengan koefisien pengaruh tidak langsung, jika koefisien pengaruh tidak langsung lebih besar dari koefisien pengaruh langsung maka variabel intervening dapat dibuktikan.

\section{HASIL DAN PEMBAHASAN Deskriptif Variabel Penelitian}

Berdasarkan hasil olah data menggunakan SmartPLS yang telah dilakukan, maka jumlah sampel yang memenuhi syarat tersebut tercapai pada angka 80 data. Distribusi statistik masing - masing variabel terdapat pada tabel 4.2 berikut:

\section{Tabel Statistik Deskriptif}




\begin{tabular}{|c|c|c|c|c|c|c|c|c|c|}
\hline & No. & Missing & Mean & Median & Min & Max & Standar... & Excess... & Skewness \\
\hline DPR & 1 & 0 & 2.354 & 2.350 & 2.300 & 2.490 & 0.031 & 4.096 & 1.475 \\
\hline ETR & 2 & 0 & 2.327 & 2.330 & 2.270 & 2.360 & 0.012 & 9.815 & -1.785 \\
\hline DER & 3 & 0 & 1.520 & 0.810 & 0.280 & 7.520 & 1.700 & 2.970 & 1.978 \\
\hline ROA & 4 & 0 & 0.154 & 0.090 & 0.020 & 0.960 & 0.166 & 7.085 & 2.398 \\
\hline SIZE & 5 & 0 & 15.712 & 15.430 & 13.130 & 20.660 & 1.517 & -0.068 & 0.534 \\
\hline
\end{tabular}

Sumber: Data Sekunder diolah 2018

Tabel diatas dapat dilihat bahwa rata - rata masing - masing variabel berada pada angka positif. Variabel DPR, ETR dan SIZE pada hasil deskriptif diatas menunjukkan nilai rata - rata lebih besar dari standar deviasi yaitu maka artinya data tersebut stabil, merata dan tidak terjadi penyimpangan. Sementara variabel DER dan ROA pada hasil deskriptif diatas menunjukkan nilai rata - rata lebih kecil dari standar deviasi meskipun tidak terpaut terlalu jauh maka artinya memiliki lebih banyak variance data.

\section{Analisis Full Model-Structural Equation Model}

Analisis hasil pengolahan data pada tahap full model SEM dilakukan dengan melakukan uji statistik. Hasil pengolahan data untuk analisis full model SEM ditampilkan pada Gambar 4.1.

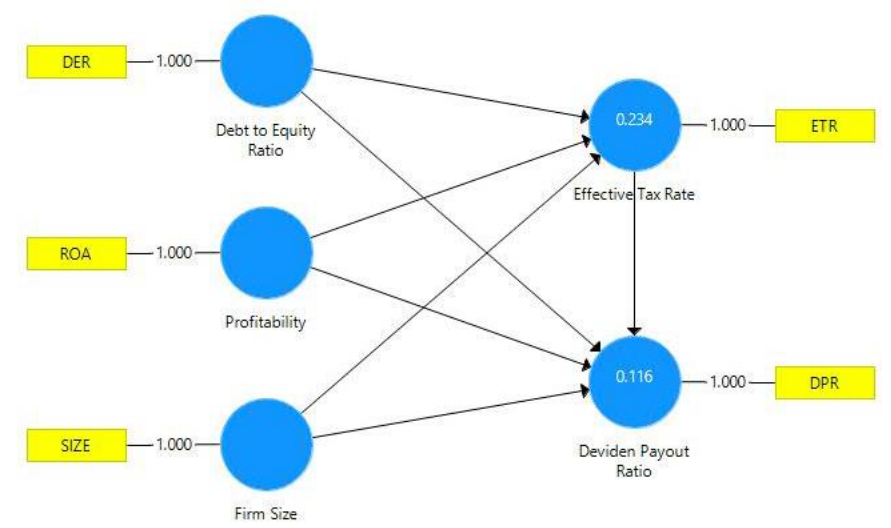

Gambar

Hasil Pengujian Full Model-Structural Equation Model (SEM)

\section{Koefisien Determinasi}

Tabel

Nilai R-Square

\begin{tabular}{|l|c|}
\hline & R- $^{\text {square }}$ \\
\hline ROA, SIZE, DER $\rightarrow$ ETR & 0.234 \\
\hline ROA, SIZE, DER,ETR $\rightarrow$ DPR & 0.116 \\
\hline
\end{tabular}

Tabel diatas diperoleh hasil Profitability, Debt to Equity Ratio, danfirm sizemempengaruhi tax rate sebesar23,4\%. Profitability, Debt to Equity Ratio, firm sizedantax rate mempengaruhi DPR (Dividen Payout Ratio) sebesar11,6\%. Uji tersebut menjelaskan bahwa masih banyak faktor diluar variabel independen yang diuji terhadap variabel dependennya.

\section{Inner Weights}


Inner Weights bertujuan untuk mengetahui hubungan antar variabel penelitian, dilihat pada gambar 4.2 dan tabel 4.4. berikut ini:

\section{Gambar Model PLS Bootstrap}

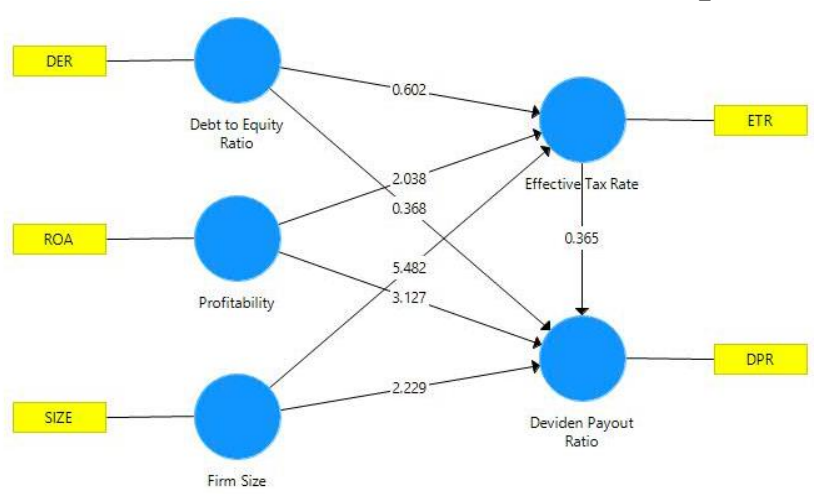

Tabel Results for Inner Weights

\begin{tabular}{|l|r|r|r|r|r|}
\hline & Original... & Sample ... & Standard ... & T Statistics... & P Values \\
\hline Debt to Equity Ratio -> Deviden Payout Ratio & -0.039 & -0.043 & 0.105 & 0.368 & 0.713 \\
\hline Debt to Equity Ratio -> Effective Tax Rate & -0.045 & -0.051 & 0.076 & 0.602 & 0.547 \\
\hline Effective Tax Rate -> Deviden Payout Ratio & 0.030 & 0.033 & 0.082 & 0.365 & 0.715 \\
\hline Firm Size -> Deviden Payout Ratio & 0.265 & 0.261 & 0.119 & 2.229 & 0.026 \\
\hline Firm Size -> Effective Tax Rate & 0.517 & 0.514 & 0.094 & 5.482 & 0.000 \\
\hline Profitability -> Deviden Payout Ratio & 0.326 & 0.338 & 0.104 & 3.127 & 0.002 \\
\hline Profitability -> Effective Tax Rate & 0.117 & 0.127 & 0.057 & 2.038 & 0.042 \\
\hline
\end{tabular}

Sumber: Data sekunder yang diolah, 2019

Berdasarkan tabel diatas diketahui Pengaruh Debt to Equity Ratio terhadap tax rate, diperoleh nilai t statistik sebesar 0.602 lebih kecil dari t tabel $( \pm 1,96)$ jadi tidak ada pengaruh Debt to Equity Ratio terhadap tax rate, semakin tinggi ataupun rendah Debt to Equity Ratio tidak mempengaruhi tinggi rendahnya tax rate perusahaan (H1 ditolak).

Pengaruh Profitability terhadap tax rate, diperoleh nilai t statistik sebesar 2.038 lebih besar dari $\mathrm{t}$ tabel $( \pm 1,96)$ jadi ada pengaruh Profitability terhadap tax rate, semakin tinggi Profitability maka semakin tinggitax rate perusahaan (H2diterima).

Pengaruh firm size terhadap tax rate, diperoleh nilai t statistik sebesar 5.482 lebih besar dari t tabel $( \pm 1,96)$ jadi ada pengaruh firm size terhadap tax rate, makin tinggi firm size maka semakin tinggitax rate perusahaan (H3 diterima).

Pengaruh Debt to Equity Ratio terhadap DPR (Dividen Payout Ratio), diperoleh nilai $\mathrm{t}$ statistik sebesar 0.368 lebih kecil dari t tabel $( \pm 1,96)$ jadi tidak ada pengaruh $D e b t$ to Equity Ratio terhadap DPR (Dividen Payout Ratio), semakin tinggi Debt to Equity Ratio tidak memiliki pengaruh apapun tehadap DPR (Dividen Payout Ratio) (H5 ditolak).

Pengaruh Profitability terhadap DPR (Dividen Payout Ratio), diperoleh nilai t statistik sebesar 3.217 lebih besar dari t tabel $( \pm 1,96)$ jadi ada pengaruh Profitability terhadap DPR (Dividen Payout Ratio), semakin tinggi Profitability maka semakin baik $D P R$ (Dividen Payout Ratio) (H4 diterima).

Pengaruh firm size terhadap DPR (Dividen Payout Ratio), diperoleh nilai $\mathrm{t}$ statistik sebesar 2.229 lebih besar dari t tabel $( \pm 1,96)$ jadi ada pengaruh firm size 
terhadap DPR (Dividen Payout Ratio), semakin tinggi firm sizemaka semakin tinggi DPR (Dividen Payout Ratio)pada perusahaan (H6 diterima).

Pengaruh tax rate terhadap DPR (Dividen Payout Ratio), diperoleh nilai $\mathrm{t}$ statistik sebesar 0.365 lebih besar dari t tabel $( \pm 1,96)$ jadi tidak ada pengaruh tax rate terhadap DPR (Dividen Payout Ratio), semakin tinggi maupun rendahtax rate maka tidak akan mempengaruhi tinggi rendahnya DPR (Dividen Payout Ratio) (H7 ditolak).

Persamaan yang dapat disusun dengan memasukkan koefisien uji inner weight pada kolom original sampel estimated.
I. $\quad$ ETR $=-0.045 \mathrm{DER}+0.117 \mathrm{ROA}+0.517 \mathrm{SIZE}$
II. $\quad \mathrm{DPR}=-0.039 \mathrm{DER}+0.326 \mathrm{ROA}+0.265 \mathrm{SIZE}+0.030 \mathrm{ETR}$

a. Persamaan I

- Jika DER mengalami peningkatan sebesar 1 poin dengan asumsi variabel lain tetap maka ETR mengalami penurunan sebesar 0.045

- Jika ROA mengalami peningkatan sebesar 1 poin dengan asumsi variabel lain tetap maka ETR mengalami peningkatan sebesar 0.117.

- Jika SIZE mengalami peningkatan sebesar 1 poin dengan asumsi variabel lain tetap maka ETR mengalami peningkatan sebesar 0.517.

b. Persamaan II

- Jika Debt to Equity Ratio mengalami peningkatan sebesar 1 poin dengan asumsi variabel lain tetap maka DPR mengalami penutunan sebesar 0.039

- Jika ROA mengalami peningkatan sebesar 1 poin dengan asumsi variabel lain tetap maka DPR mengalami peningkatan sebesar 0.326

- Jika SIZE mengalami peningkatan sebesar 1 poin dengan asumsi variabel lain tetap maka DPR mengalami peningkatan sebesar 0.265.

- Jika ETR mengalami peningkatan sebesar 1 poin dengan asumsi variabel lain tetap maka DPR mengalami peningkatan sebesar 0.030.

\section{Uji Mediating}

Menurut Baron dan Kenny (dalam Ghozali, 2006), suatu variabel disebut variabel intervening jika variabel tersebut ikut mempengaruhi hubungan variabel prediktor (independen) dan variabel kriterion (dependen). Pengujian mediasi dapat dilakukan dengan prosedur yang dikembangkan oleh Smart PLS Versi 3,0 dan menui pilihan Specisif Indirect Effect.

Tabel Specific Indirect Effect

\begin{tabular}{|l|r|r|r|r|r|}
\hline & Original ... & Sample ... & Standard... & T Statistics ... & P Values \\
\hline Debt to Equity Ratio - Effective Tax Rate - > Deviden Payout Ratio & -0.001 & -0.003 & 0.008 & 0.162 & 0.872 \\
\hline Firm Size -> Effective Tax Rate $>$ Deviden Payout Ratio & 0.016 & 0.015 & 0.043 & 0.362 & 0.717 \\
\hline Profitability $\rightarrow$ Effective Tax Rate $>>$ Deviden Payout Ratio & 0.004 & 0.004 & 0.012 & 0.290 & 0.772 \\
\hline
\end{tabular}

Sumber: diolah dengan Smart PLS 3.0.

a. Pengaruh Debt to Equity Ratio terhadap DPR (Dividen Payout Ratio) melalui Tax rate

Berdasarkan tabel diatas, pengujian mediasi dapat diketahui bahwa tax rate tidak terbukti sebagai mediasi antara Debt to Equity Ratio terhadap DPR (Dividen Payout Ratio) karena diperoleh nilai t-stat $=0.162$ dan $\operatorname{sig}=0,872$. Karena tingkat 
signifikansi t-statistik $<1,96$ dan tidak signifikan maka tax rate tidak terbukti sebagai variabel mediasi Debt to Equity Ratio terhadap DPR (Dividen Payout Ratio).

b. Pengaruh Profitability terhadap DPR (Dividen Payout Ratio) melalui Tax rate Berdasarkan tabel diatas, pengujian mediasi dapat diketahui bahwa tax rate tidak terbukti sebagai mediasi antara Profitability terhadap DPR (Dividen Payout Ratio) karena diperoleh nilai $\mathrm{t}$-stat $=0.290 \mathrm{dan} \operatorname{sig}=0,772$. Karena tingkat signifikansi tstatistik $<1,96$ dan tidak signifikan maka tax rate tidak terbukti sebagai variabel mediasi Profitability terhadap DPR (Dividen Payout Ratio).

c. Pengaruh Firm size terhadap DPR (Dividen Payout Ratio) melalui Tax rate

Berdasarkan tabel diatas, pengujian mediasi dapat diketahui bahwa tax rate tidak terbukti sebagai mediasi antara Firm size terhadap DPR (Dividen Payout Ratio) karena diperoleh nilai t-stat $=0.362 \mathrm{dan} \operatorname{sig}=0,717$. Karena tingkat signifikansi tstatistik $<1,96$ dan tidak signifikan maka tax rate tidak terbukti sebagai variabel mediasi Firm sizeterhadap DPR (Dividen Payout Ratio).

\section{Pembahasan}

\section{Debt to Equity RatioTidak Berpengaruh terhadap Effective Tax rate}

Berdasarkan nilai statistik, Pengaruh Debt to Equity Ratio terhadap tax rate, diperoleh nilai t statistik sebesar 0.547 lebih kecil dari t tabel $( \pm 1,96)$ jadi tidak ada pengaruh Debt to Equity Ratio terhadap tax rate, semakin tinggi ataupun rendah Debt to Equity Ratio tidak mempengaruhi tinggi rendahnya tax rate perusahaan. Jadi hipotesis pertama yang mengatakan bahwa Debt to Equity Ratio berpengaruh terhadap tax rate perusahaan ditolak.

Debt to Equity Ratio merupakan kemampuan perusahaan untuk memenuhi seluruh kewajiban jangka pendeknya yang telah jatuh tempo, dengan menggunakan aktiva jangka pendek yang dimilikinya. Ketersediaan kas yang mencukupi akan lebih berpeluang untuk mengurangi hutang, meskipun kewajiban jangka pendek belum jatuh tempo manajemen akan berusaha menutup kewajiban jangka pendeknya atau manajemen akan lebih mengoptimalisasikan pemanfaatan dana segar yang ada diperusahaan misalnya untuk investasi. Sebagian investor ada yang berasumsi bahwa terlalu tingginya Debt to Equity Ratio perusahaan kurang terlalu bagus karena pemanfaatan alokasi dana kurang optimal. Pengendalian tingkat hutang merupakan tanggung jawab internal perusahaan. Manajemen tetap akan dapat mengelola laba dengan baik agar tarif pajak efektif berada di angka yang stabil.

Penelitian ini tidak konsisten dengan hasil penelitian Hanum dan Zulaikha (2013), Alfandia (2017) mengungkapkan pula bahwa perusahaan lebih memilih memperbesar hutang daripada modal sendiri karena ada keuntungan penghematan biaya pajak sementara jika menggunakan modal sendiri, biaya hutang akan lebih kecil dan berdampak pada laba yang meningkat sebagai dasar perhitungan pajak.

\section{Profitability berpengaruh dengan Effective Tax rate}

Berdasarkan nilai statistik, Pengaruh Profitability terhadap tax rate, diperoleh nilai $\mathrm{t}$ statistik sebesar 0.042 lebih besar dari $\mathrm{t}$ tabel $( \pm 1,96)$ jadi ada pengaruh Profitability terhadap tax rate, semakin tinggi Profitability maka semakin tinggi tax rate perusahaan.Jadi hipotesis kedua yang mengatakan bahwa Profitability berpengaruh terhadap tax rate perusahaan diterima.

Profitability adalah kemampuan perusahaan memperoleh laba dalam hubungannya dengan penjualan, total aktiva maupun modal sendiri. Alfandia (2017) 
mengungkapkan bahwa apapun kebijakan pendanaan yang digunakan, pajak menjadi pertimbangan yang paling penting. Sebuah perusahaan akan berusaha untuk membayar hutang pajak yang lebih rendah. Faktor pajak sendiri memiliki perhitungan yang terkait dengan laba setelah pajak (Earnings After Tax - EAT).Maka dari itu ketika prfotabilitas perusahaan meningkat maka tarif pajak efektif akan ikut meningkat.

Berdasarkan temuan diatas, besarnya Profitability yang mempengaruhi besar kecilnya tax rate sudah sesuai dengan penelitian Darmawan dan Sukarta (2014) memberikan bukti bahwa ROA (Return on Asset) yang merupakan proksi dari Profitability perusahaan dapat mempengaruhi perusahaan dalam melakukan tinggi rendahnya laba yang dibayarkan.

\section{Firm Size Berpengaruh terhadap Tax rate}

Berdasarkan nilai statistik, Pengaruh firm size terhadap tax rate, diperoleh nilai t statistik sebesar 5.482 lebih besar dari $\mathrm{t}$ tabel $( \pm 1,96)$ jadi ada pengaruh firm size terhadap tax rate, makin tinggi firm size maka memiliki pengaruh terhadap tinggi rendahnya tax rate perusahaan.Jadi hipotesis ketiga yang mengatakan bahwa firm size berpengaruh terhadap tax rate perusahaan diterima.

Firm size atau ukuran perusahaan merupakan perubahan total aktiva yang dimiliki perusahaan (Setiawan, 2016). Sumber daya manusia yang banyak dan berpotensi dalam perpajakan yang umumnya dimiliki oleh perusahaan besar diperlukan agar dalam pengelolaan pajak yang dilakukan oleh perusahaan dapat maksimal untuk menekan beban pajak perusahaan (Darmawan dan Sukarta, 2014). Semakin besar perusahaan maka semakin tinggi tarif pajak efektif mengingat obyek pajak yang dikenakan tarif lebih kompleks dan lebih banyak sehingga kegiatan pada divisi perpajakan di perusahaan besar lebih banyak karena menghitung nominal yang lebih besar.

Temuan ini konsisten dengan hasil penelitian Dewinta dan Setiawan (2016) menyatakan bahwa menyatakan bahwa firm size berpengaruh positif dan signifikan terhadap tax rate.

\section{Debt to Equity Ratio Tidak Berpengaruh DPR (Dividen Payout Ratio)}

Berdasarkan nilai statistik, Pengaruh Debt to Equity Ratio terhadap DPR (Dividen Payout Ratio), diperoleh nilai t statistik sebesar 0.368 lebih kecil dari t tabel $( \pm 1,96)$ jadi tidak ada pengaruh Debt to Equity Ratio terhadap DPR (Dividen Payout Ratio), semakin tinggi Debt to Equity Ratio tidak memiliki pengaruh apapun tehadap DPR (Dividen Payout Ratio). Jadi hipotesis kelima yang mengatakan bahwa Debt to Equity Ratio berpengaruh terhadap DPR (Dividen Payout Ratio) ditolak.

Debt to Equity Ratio merupakan kemampuan perusahaan untuk memenuhi seluruh kewajiban jangka pendeknya yang telah jatuh tempo, dengan menggunakan aktiva lancar yang dimilikinya. Debt to equity ratio merupakan rasio yang digunakan untuk mengukur tingkat Debt to Equity Ratio(penggunaan utang) terhadap total shareholders' equity yang dimiliki perusahaan (Ang 1997). Faktor ini mencerminkan kemampuan perusahaan dalam memenuhi seluruh kewajibannya yang ditunjukkan oleh beberapa bagian modal sendiri yang digunakan untuk membayar hutang. Investor tidak melihat Debt to Equity Ratio perusahaan. Ketika Debt to Equity Ratio tinggi maka manajemen kurang mampu optimaisasi pendanaan yang tersedia. Ketika Debt to Equity Ratio rendah harus berhati-hati dalam mengelola hutang jangka pendek. Tinggi rendahnya Debt to Equity Ratio bagi investor belum tentu mencerminkan kondisi perusahaan yang sebenarnya sehingga DPR (Dividen Payout Ratio) tidak mengalami perubahan. Mengingat tingkat hutang yang tinggi memiliki dua asumsi yakni asumsu pengembangan yang menyebabkan peningkatan DPR (Dividen Payout Ratio) dan 
asumsi resiko yang menyebabkan penurunan DPR (Dividen Payout Ratio). Sama halnya dengan tingkat hutang yang rendah.

Temuan penelitian ini yang mengatakan bahwa Debt to Equity Ratio tidak berpengaruh terhadap DPR (Dividen Payout Ratio) sejalan dengan penelitian Janifairus, dkk (2013)di ketahui bahwa Debt to Equity Ratio tidak berpengaruh terhadap DPR (Dividen Payout Ratio)dan bertolak belakang dengan penellitian Perpatih (2016) yang menunjukkan hasil bahwa Debt to Equity Ratio berpengaruh terhadap DPR (Dividen Payout Ratio).

\section{Profitability Berpengaruh terhadap DPR (Dividen Payout Ratio)}

Berdasarkan nilai statistik, Pengaruh Profitability terhadap DPR (Dividen Payout Ratio), diperoleh nilai t statistik sebesar 3.217 lebih besar dari t tabel $( \pm 1,96)$ jadi ada pengaruh Profitability terhadap DPR (Dividen Payout Ratio), semakin tinggi Profitability maka semakin baik DPR (Dividen Payout Ratio). Jadi hipotesis keempat yang mengatakan bahwa Profitability berpengaruh terhadap DPR (Dividen Payout Ratio) diterima.

Kemampuan perusahaan untuk menghasilkan laba akan mempengaruhi kebijakan para investor atas investasi yang dilakukannya. Sedangkan bagi perusahaan, Profitability dapat digunakan untuk mengevaluasi atas efektivitas pengelolaan perusahaan dan merupakan salah satu dasar penilaian kondisi perusahaan itu sendiri. Tingkat Profitability yang tinggi menunjukkan prospek perusahaan semakin bagus sehingga menarik para investor menanamkan dananya kemudian manajemen berusaha memberikan timbal balik dengan mebagikan dividen sesuai dengan harapan investor agar investor tetap setia. Kebijakan jumlah pembagian dividen perusahaan dipengaruhi oleh Profitability mampu memberikan kesejahteraan yang lebih baik bagi investor dengan cara meningkatkan rasio dividen yang dibagikan. Situasi lain ketika perusahaan sedang dalam kondisi bertahan dengan tingkat keuntungan rendah maka investor akan mau mengerti penurunan pembagian dividen dengan alasan mempertahankan kondisi dan kebutuhan prioritas usaha.

Hasil penelitian ini tidak konsisten dengan penelitian Laim, dkk(2015) menunjukkan bahwa Profitabilitytidak berpengaruh signifikan terhadap DPR (Dividen Payout Ratio). Sementara hasil ini menunjukkan konsistensi hasil pada penelitian Perpatih (2016), Janifairus, dkk (2013), Nufiati (2015), Utami dan Robin (2015) yang mengatakan bahwa Profitability berpengaruh signifikan terhadap DPR (Dividen Payout Ratio).

\section{Firm size Berpengaruh terhadap DPR (Dividen Payout Ratio)}

Berdasarkan nilai statistik, Pengaruh firm size terhadap DPR (Dividen Payout Ratio), diperoleh nilai $t$ statistik sebesar 2.229 lebih besar dari t tabel $( \pm 1,96)$ jadi ada pengaruh firm size terhadap DPR (Dividen Payout Ratio), semakin tinggi firm size semakin tinggi DPR (Dividen Payout Ratio).Jadi hipotesis keenam yang mengatakan bahwa firm size berpengaruh terhadap DPR (Dividen Payout Ratio) diterima.

Firm size adalah merupakan ukuran perusahaan yang menunjukkan besar kecilnya perusahaan yang dapat dilihat dari keseluruhan aset yang dimiliki. Perusahaan yang besar cenderung memiliki kemampuan yang baik dalam menghasilkan keuntungan, kemampuan mengembangkan usaha dan kemampuan menyejahterakan investor. Menurut Pasadena (2013) perusahaan yang memiliki aset besar atau yang sudah mapan cenderung lebih mempunyai akses yang lebih mudah dan lebih luas untuk fleksibilitas dan kemampuan perusahaan untuk memperoleh dana yang lebih besar dalam pasar modal dibandingkan dengan perusahaan yang mempunyai size kecil.Hal inilah yang 
menjadi pembeda reputasi perusahaan besar dan kecil. Perusahaan besar cenderung akan memberikan DPR lebih tinggi dibandingkan dengan perusahaan kecil.

Hasil penelitian ini tidak konsisten dengan penelitian Suroto (2014) yang menghasilkan bukti bahwa Firm Size tidak signifikan terhadap DPR (Dividen Payout Ratio) namun konsisten dengan penelitianMarietta dan Sampurno (2013) menyatakan bahwa menyatakan bahwa firm size berpengaruh positif dan signifikan terhadap dividend payout ratio. Penelitian tersebut juga sejalan dengan penelitian Utami dan Robin (2015)yang membuktikan bahwa ukuran perusahaan dapat mempengaruhi DPR.

\section{Tax rate Tidak Berpengaruh terhadap DPR (Dividen Payout Ratio)}

Berdasarkan nilai statistik, Pengaruh tax rate terhadap DPR (Dividen Payout Ratio), diperoleh nilai t statistik sebesar 0.715 lebih kecil dari t tabel $( \pm 1,96)$ jadi tidak ada pengaruh tax rate terhadap DPR (Dividen Payout Ratio), semakin tinggi ataupun rendah tax rate maka tidak mempengaruhi tinggi rendahnya DPR (Dividen Payout Ratio). Jadi hipotesis ketujuh yang mengatakan bahwa tax rate berpengaruh terhadap DPR (Dividen Payout Ratio) ditolak.

Dalam penelitian Bansaleng, dkk (2014) menunjukkan bahwa laba yang ditahan akan dijadikan acuan dalam membayar pajak. Meskipun pihak investor tidak terlalu menyukai keputusan yang diambil oleh pihak manajemen perusahaan yang ingin menahan laba untuk dijadikan laba ditahan. Namun manajemen memiliki keputusan tersendiri dalam memilih untuk menahan atau membagikan dividen. Tingginya tarif pajak yang dibayarkan mencerminkan bahwa laba yang mampu dihasilkan perusahaan semakin besar. Investor mengetahui kabar baik tersebut melalui lapooran keuangan sehingga berharap pembagian dividen yang lebih tinggi. Namun manajemen memiliki kebijakan menentukan peluang baik dalam sisi kepercayaan pendanaan dari investor maka manajemen merealisasikan DPR yang lebih tinggi / rendah mengingat tarif pajak yang dibayarkan tinggi akibat laba meningkat.

Penelitian ini tidak sejalan dengan penelitian Gill, et al (2010) menunjukan bahwa tax rate suatu perusahaan berpengaruh terhadap DPR (Dividen Payout Ratio). Kenaikan dan penurunan kewajiban WP badan dalam membayar pajak akan mempengaruhi preferensi untuk pembayaran pajak yang berdampak pada rasio dividen yang dibagikan.

Tax rate Tidak Terbukti Sebagai Mediasi

Berdasarkan nilai statistic pada table 4.5, pengujian mediasi dapat diketahui bahwa tax rate tidak terbukti sebagai mediasi, baik pada variable DER terhadap DPR dengan nilait-stat $=0,162$ dan sig $=0,872$, Profitability terhadap DPR dengan nilait-stat $=0,290$ dan sig $=0,772$ dan Firmsize terhadap DPR dengan nilait-stat $=0,362$ dan sig $=$ 0,717 .

Hal ini dikarenakan pada tax preference theory pajak yang dimaksudkan adalah pajak yang dikenakan atas dividen yaitu menyangkut pajak atas investor itu sendiri, sedangkan data effective tax rate yang digunakan adalah data atas pajak yang dikenakan pada perusahaan.

\section{PENUTUP}

\section{Kesimpulan} berikut:

Berdasarkan dari hasil penelitian diatas dapat ditarik kesimpulan sebagai 
1. Terdapat dua varibel yang berpengaruh terhadap tax rate yaitu variabel Profitability dan Firm Size, dan variabel Debt to Equity Ratiotidak berpengaruh terhadap tax rate

2. Terdapat $d u a$ varibel yang berpengaruh terhadap DPR (Dividen Payout Ratio) yaitu variabel Profitability dan Firm Size, dan variabel Debt to Equity Ratio dan tax rate tidak berpengaruh terhadap tax rate

3. Tax ratetidak terbukti sebagai variabel intervening antara firm size, Debt to Equity Ratio, danProfitabilityterhadapDPR (Dividen Payout Ratio).

\section{Implikasi Manajerial}

1. Gill, et al (2010), Perpatih (2016), Janifairus, dkk (2013), Nufiati (2015), Utami dan Robin (2015) menunjukkan bahwa Profitability dan firm sizeberpengaruh pada DPR (dividen payout ratio). Manajemen perusahaan manufaktur baiknya menjaga Profitability dan firm sizeperusahaan tidak meningkat. Bagaimanapun Profitability menunjukkan prospek usaha yang baik dimata investor dan total aset yang stabil juga akan mempengaruhi dividen yang dibayarkan.

2. DPR (Dividen Payout Ratio)perusahaan yang rutin membagi dividen menjadi tolok ukur investor dalam berinvestasi. DPR (Dividen Payout Ratio) yang baik ditunjang oleh faktor pendorong berupa Profitability yang tinggi.

\section{Implikasi Teoritis}

1. Penelitian ini memberikan kontribusi teoritis dibidang manajemen keuangan khususnya mengenai faktor-faktor yang mempengaruhi tax rate dan DPR (Dividen Payout Ratio).

2. Variabel Profitability dan firm sizedalam penelitian ini terbukti mempengaruhi DPR (Dividen Payout Ratio)

3. Variabel Debt to Equity Ratio dan ETR tidak mempengaruhi tax ratedanDPR (Dividen Payout Ratio).

4. Penelitian ini memberikan celah untuk mengisi keterbatasan penelitian dengan menambahkan variabel independen yang mempengaruhi variabel dependen mengingat R-Square kecil.

\section{Keterbatasan Penelitian}

1. Data yang diperoleh dalam menguji Tax Rate sebagai variabel intervening hanya diperoleh data berupa data pajak pada perusahaan dan data data pajak pribadi atas investor tidak didapatkan sehingga dalam pengujian Tax Rate berdasarkan tax preference theory tidak dapat dilakukan secara maksimal, karena dalam menguji varibel Tax Rate sebagai variabel intervening akan terlihat jika menggunakan Average Effective total tax rate yaitu besaran biaya pajak perusahaan di tambah pajak property ditambah bunga atas pajak pribadi dan dividen di bagi dengan pendapatan modal.

2. Sampel yang kecil dan dari berbagai sektor yang mempunyai karakteristik yang berbeda pada setiap sektor perusahaan yang di jadikan sampel sangat mempengaruhi hasil penelitian.

\section{Agenda Penelitian Yang Akan Datang}

1. Tax rate perlu dilakukan pengujian lagi menggunakan Average Effective total tax rate yaitu besaran biaya pajak perusahaan di tambah pajak property ditambah bunga atas pajak pribadi dan dividen di bagi dengan pendapatan modal, sehingga diperoleh hasil yang lebih akurat baik sebagai variabel intervening maupun variabel moderating 
2. Memperluas periode pengamatan yaitu dengan memperpanjang periode pengamatan sehingga akan diperoleh hasil yang lebih luas 


\section{DAFTAR PUSTAKA}

Abdullah,S (2001). "Hubungan antara Kepemilikan Manajerial, Struktur Modal dan Kebijakan Dividen : Suatu Analisa Simultan”. Jurnal Manajemen \& Bisnis Vol.3 No.2 Mei. p.159-176

Alfandia, N. S. (2018). Pajak dan Struktur Modal Perusahaan Manufaktur di Indonesia. Berkala Akuntansi dan Keuangan Indonesia, 3(1).

Ang, Robert (1997). "Buku Pintar Pasar Modal Indonesia (The Intelligent Guide toIndonesian Capital Market)". Media Soft Indonesia.

Aunalal, Ardnolus, (2011)," Pengaruh Size, Profitability\& Ownership Structure Sebagai Faktor-faktor yang Mempengaruhi Tax Rate Perusahaan”, Fakultas Ekonomika dan Bisnis Universitas Gajah Mada

Bansaleng, Resky .V, (2014),'Kebijakan Hutang, Struktur Kepemilikan Dan Profitabilitas Terhadap Kebijakan Dividen Pada Perusahaan Food And Beverage Di Bursa Efek Indonesia", Universitas Sam Ratulangi Manado

Brigham, Eugene, and Houston, J.F, (2004), "Fundamentals of Financial Management(terjemahan)", Salemba Empat, Jakarta.

Darmawan, I. G. H., \& Sukartha, I. M. (2014). Pengaruh Penerapan Corporate Governance, Leverage, Roa, dan Ukuran Perusahaan pada Penghindaran Pajak. EJurnal Akuntansi, 143-161.

Dewinta, Ida Ayu Rosa dan Setiawan, Putu Ery. (2016). "PengaruhUkuran Perusahaan, Umur Perusahaan, Profitabilitas, Leverage,dan Pertumbuhan Penjualan Terhadap TaxAvoidance".E-JurnalAkuntansi Universitas Udayana. 14(3): h:1584-1613

Ferdinand, Augusty (2006), Metode Penelitian Manajemen: Pedoman Penelitian untuk Penulisan Skripsi, Tesis dan Disertasi Ilmu Manajemen, Badan Penerbit Universitas Diponegoro, Semarang

Gill, Amarjit., Nahum Biger dan Rajendra Tibrewala. (2010). "Determinants of Dividend Payout Ratios: Evidence From Unites State". The Open Business Journal, 3, pp: 8-14

Gordon dan lintner. (1956), "Distributio Of Incomes Of Corporations among dividens, Retained Earnings and Taxes", The American Economic Review 46, 97-113

http//:www.idx.co.id

Hanafi, Mamduh M dan Abdul Halim, (2005), Analisis Laporan Keuangan, Edisi Kedua, Yogyakarta : STIE YKPN.

Hanafi M. Mamduh. (2004). Manajemen Keuangan. Yogyakarta: BPFE

Hanum Hashemi Rodhian dan Zulaikha, (2013). "Pengaruh Karakteristik Corporate Governance terhadap Effective Tax Rates (Studi empiris pada BUMN yang terdaftar di BEI 2009-2011)".'Universitas Diponegoro. Volume 2 Nomor 2 Tahun 2013, (Halaman 1-10) ISSN:2338-3806

Imam, Ghozali.(2014). Structural Equation Modeling, Metode Alternatif dengan Partial Least Square (PLS). Edisi 4. Semarang : Badan Penerbit Universitas Diponegoro

Janifairus,J.B, Hidayat, R dan Husaini,A.(2013), "Pengarug Return On Asset, Debt to Equity Ratio, Assets Growth dan Cash Ratio terhadap Dividend Payout Ratio", Universitas Brawijaya Malang

Jensen, M.C. \& Meckling, W.H. (1976). “Theory of The Form: Managerial Behavior, Agency Cost, and Ownership Structure. Journal of Financial Economic, Vol.3 pp.305-360. 
Laim,Wisriati, Nangoy,S.C, dan Murni,Sri.(2015). “Analisis Faktor-Faktor yang Mempengaruhi Dividensd Payout Ratio pada Perusahaan yang terdaftar di Indeks LQ-45 Bursa Efek Indonesia", Universitas Sam Ratulangi Manado

Maria, M.R. dan Tommy Kurniasih.(2013). Pengaruh Return on Assets, Leverage, Corporate Governance, dan Kompensasi Laba Fiskal pada Tax Avoidance. Buletin Studi Ekonomi, 18(1):h:58-66. Fakultas Ekonomi Universitas Udayana. Marieta, Unzu dan Sampurno,Joko.(2013), "Analisis Pengaruh Cash Ratio, Return On Assets, Growth, Firm Size, Debt to Equity Ratio Terhadap Dividend Payout Ratio : ( Studi Pada Perusahaan Manufaktur Yang Terdaftar di Bursa Efek Indonesia Tahun 2008-2011)", Universitas Diponegoro.

Nufiati, Nurul Masruri Bagus.(2015) "Pengaruh Profitabilitas dan Likuiditas Terhadap Kebijakan Dividen Kas pada Perusahaan Pefindo 25", STIESIA Surabaya

Pasadena, Rizka Persia.(2013).“Pengaruh Likuiditas, Leverage, Profitabilitas dan Ukuran Perusahaan terhadap Kebijakan Dividen pada Perusahaan Manufaktur yang terdaftar di Bursa Efek Indonesia", Universitas Islam Negeri Syarif Hidayatullah Jakarta

Perpatih, Zuhafni ST. (2016)."Pengaruh ROA Dan DER Terhadap Dividend Payout Ratio (DPR) Pada Perusahaan Manufaktur Sektor Industri Dasar Dan Kimia Yang Terdaftar Di Bursa Efek Indonesia."e-Jurnal Apresiasi Ekonomi Volume 4, Nomor 3, September 2016

Riyanto, Bambang. (2001). “Dasar-Dasar Pembelanjaan Perusahaan”. Yogyakarta: BPFE

Suroto.(2014). "Faktor - Faktor Yang Mempengaruhi Dividend Payout Ratio Pada Perusahaan Yang Terdaftar di Bursa Efek Indonesia Periode 2010 - 2012”, Universitas 17 Agustus 1945 (UNTAG) Semarang

UU Nomor 36 Tahun 2008 tentang Pajak Penghasilan

Utami,Gayatri Kurnia dan Robin.(2015).“Analisis Faktor-Faktor yang Mempengaruhi Rasio Pembayaran Dividen pada Perusahaan yang terdaftar di Bursa Efek Indonesia", Universitas Internasional Batam.

Tiaras, I., \& Wijaya, H. (2015). Pengaruh Likuiditas, Leverage, Manajemen Laba, Komisaris Independen dan Ukuran Perusahaan Terhadap Agresivitas Pajak. Universitas Tarumanagara. Journal of Accounting, 19(3).

Wicaksana, I Gede Ananditha.(2012)."Pengaruh Cash Ratio, Debt To Equity Ratio, Dan Return On Asset Terhadap Kebijakan Dividen Pada Perusahaan Manufaktur Di Bursa Efek Indonesia”, Universitas Udayana Denpasar 